\title{
Challenges towards Promoting, Organizing and Conducting International Business and Management Education at Graduate level in Emerging Developing Economies: A practitioner's perspective
}

\author{
Aaron Loh PhD \\ Graduate School of Business \\ Assumption University of Thailand \\ Thailand
}

\begin{abstract}
University education in emerging economies at graduate level, during the last two decades, had started to pay attention to the field of economics and business management training. Today, just as happened half a century ago in universities of developed countries, most universities of good repute and popularity in the younger developing and emerging economies are beginning to have business specialization more popular than all other academic disciplines in their university. However, most of these academic institutions, are nevertheless still conducting their courses in the mother tongue of the specific nation where they are located.
\end{abstract}

The present author had the privilege to have worked first hand for some 25 years in business world globally before retiring to the academic arena for more than a decade to teach and implement programs for international business and management education in Thailand. Particularly during the last 3 years, there were many opportunities that were worked on for collaboration and networking with different universities in the southeast Asian region towards organizing graduate level International business education in these emerging and developing nations. This presentation introduces the many challenges faced over the years in those environment.

Keywords: Challenges, emerging economies, international business and management education, practitioner's perspective 


\section{International Academic Conference on Management \& Economics}

\section{Introduction}

\subsection{Historical development of internationalization of tertiary education}

Before the Second World War, most countries, with a few exception to those that were colonized by developed nations, have their education system conducted entirely in their mother tongue of the country. The natural situation with education in mother tongue of the country largely continued to this day.. Upon the War, huge efforts were invested by the United Nations, and the developed economies to encourage the opening up of every country in the world to engage in mutual trade for economic growth and mutual benefits; a process quickly coined as globalization. Foreign direct investments and opening of foreign offices in the host countries soon followed. The development creates an attractive career opportunity for graduates who are able to communicate and operate in English, the generally accepted language for doing business. Beginning from the 80's, globalization activities has intensified, leading to some aspiring parents sending their children to attend academic institutions with international program in higher education. Whilst academic institutions introducing international program to their curriculum are rapidly growing, they nevertheless represents a very small minority in most of the national education system of the emerging economies. Seameo (2017).

\section{Objectives}

The purpose of this paper is to highlight the challenges, development and opportunities in the internationalisation of higher education in economics and management experienced by the emerging economies in South East Asia.

\section{Methodology/Approach}

This presentation represents a learning summary of the author in the position of the Director of Universities Collaboration and Networking interacting with different universities in the South East Asian region during a three-year period between 2017-2019.

\section{Findings}

\subsection{Challenges in internationalization of higher education.}




\section{International Academic Conference on Management \& Economics}

\section{4..1.1 Teaching and learning in English}

Whilst English is more widely used than before in most countries nowadays, and more children are learning it as a subject in school, nevertheless, the teaching and learning of

English as an adult for the purpose of gaining competency for professional usage is quite another matter. This is made more difficult where the teaching and learning are being conducted in an environment with a presence usually of a much more dominant mother tongue. Experience has showed that the outcome of the teaching and learning is not as effective as it should be for the purpose of learning business at higher education. Waterworth (2016)

\subsubsection{The lacking in confidence to express in their newly acquired English}

Following from the above, even if the learners had learned well and passed all the necessary written and oral tests, as often observed, many of the learners do not have the confidence to express themselves individually in English when called upon to do so. The general lack of individualism is perhaps related to the cultural behavior of collectivism. Tridinanti (2018)

\subsubsection{Textbooks and curriculum}

Text books and curriculum used today in higher education especially on the subject of business in the emerging economies mostly follow those that are written by experienced authors in developed countries. Very often, for expediency, the entire textbook is adopted and used in classroom for teaching and learning with student assignments picked from them without any modification. This can be easily understood and accepted because for these young developing countries such as those found in the emerging economies such as found in Asean, the majority of the university instructors are still in the mode of busily teaching than research and publication specific to their own market and business environment and consumer behavior. Whilst many may justify that the concepts and theories in these books are well proven, unfortunately, these textbooks are less than satisfactory when applicability is taken into consideration with respect to the different stages of the market development, the resourcefulness and experience of the business corporates, the maturity and the different behavior of the consumers as well as the governance and regulations of the government of the day. Over time, with the growth of the developing countries and their economy, this unsatisfactory state of affairs can be changed and improved. Perhaps this is the time to catch up together with the developed world with our own unique specific environment focusing on sustainability and sustained development guided by the sustained development goals of the United Nations. SEAMEO (2017)

\subsubsection{The problem of rote learning and distraction from mobile phones}

It was consistently observed that rote learning and distraction by computers, and mobile phones and pads are the major obstacles towards effective learning by students in the business schools 


\section{International Academic Conference on Management \& Economics}

globally. The present authors opined that the lack of motivation by the helpless monotonous use of the often-irrelevant textbooks written by authors of a different culture for different settings may have majorly contributed to the negative teaching and learning observations.

\subsubsection{Disruption by Artificial Intelligence (AI)}

Whilst the winner of the debate between the Optimists and the Pessimists is yet to be settled, a few conclusions are clear and definite in the next few years a) There will be job losses b) Many jobs that were once available will no longer be c) Job losses will be mostly replaced by robots and machines and by those who have different expertise This is not surprising from the rapid development in AI technology in recent years What is very surprising is that most higher education institutions especially those in the emerging economies, have not started preparing for

this major business environmental transformation in having their program curriculum and courses updated. Popenici and Kerr (2017)

\section{Opportunities}

It is noteworthy and obvious that the term Internationalization discussed in this presentation refers to English as the global business language. It needs to be emphasized that it is very likely that in the lifetime of all the audience participating in the discussion, internationalization will have a new business language in Chinese. And success will be assured to those who can master the new language of business.

\section{Conclusion}

In conclusion, students in the emerging economies such as those in South-East Asia are witnessed to be very eager, and some even coping well in their efforts towards internationalization during this era of Industry 4.0. All the challenges highlighted in this report can quite easily be overcome when they are brought to focus.

\section{References}

1) SEAMEO (2017). Guidebook to Education Systems and Reforms in Southeast Asia and China. Bangkok, Thailand: Southeast Asian Ministers of Education Organisation

2) Wentworth, P. (2016)" Teaching English in Asean" Indonesian Journal of Applied Linguistics, Vol. 5 No. 2, January 2016, pp. 154-166

3) Tridinanti G (2018)` The Correlation between Speaking Anxiety, Self-Confidence, and Speaking Achievement of Undergraduate EFL Students of Private University in Palembang“, International Journal of Education \& Literacy Studies, Vol 6 Issue 4 pp35:39 
International Academic Conference on Management \& Economics

4) Popenici S and Kerr S (2017)“" Exploring the impact of artificial intelligence on teaching and learning in higher education"Research and Practice in Technology Enhanced Learning $12: 22 \mathrm{pp}$ 